\title{
Properties of Fish Gastric Hyaluronidase
}

\author{
Manabu KitamiKado* and Hiroshi Yamamoto*
}

(Received June 15, 1972)

\begin{abstract}
The properties of hyaluronidase prepared from gastric mucosa of mackerel were studied. Determination of the activity in a 1:2 dilution of Mcllvalne buffer revealed an optimum $\mathrm{pH}$ of 4.8 , which shifted to 2.8 with the addition of $\mathrm{NaCl}$ up to a concentration of $0.15 \mathrm{M}$. Various chlorides such as $\mathrm{NaCl}, \mathrm{KCl}$ and $\mathrm{MgCl}_{2}$ enhanced the activity, and their effect might be attributed to $\mathrm{Cl}^{-}$. At a concentration of $10^{-4} \mathrm{M} \mathrm{Zn}^{++}$enhanced the activity, although $\mathrm{Ag}^{+}$and $\mathrm{Cu}^{++}$scarcely affected and $\mathrm{Hg}^{++}$inhibited it. Polycation increased the activity; on the contrary, polyanion inhibited it. The maximum activity was found at approximately $50^{\circ} \mathrm{C}$ under the conditions tested. The MICHAELIS constant for potassium hyaluronate was $0.50 \mathrm{mg}$ per $\mathrm{ml}$. The molecular weight was estimated to be approximately 56,000 by the gel filtration method.
\end{abstract}

In the previous papers ${ }^{1-3)}$ the authors reported the presence of hyaluronidase which acts as a $\mathrm{N}$-acetylhexosaminidase in the stomach of certain fish. Because of an interest in its peculiar origin, properties of the hyaluronidase are investigated in the present work.

\section{Materials}

Fish gastric hyaluronidase. The electrophoretically homogeneous enzyme ${ }^{3\rangle}(10,000$ Terbidity Reducing Unit of TOLKSDORF ${ }^{4} / \mathrm{mg}$ protein) prepared from gastric mucosa of mackerel, Scomber japonicus, was used.

Reagents. Crude potassium hyaluronate of human unbilical cord was kindly supplied by Sansei Seiyaku Co. Ltd. (Japan) and purified by the method of MATHEws ${ }^{53}$. Analysis of the purified hyaluronate gave the following values: hexosamine, 36.5\% (GARDELL's method $\left.{ }^{6}\right)$; uronic acid, $40.5 \%$ (carbazole method $\left.{ }^{7}\right)$; sulfate $0.1 \%$ (benzidine method ${ }^{8}$ ). Super special grade of chondroitin sulfates A, C and D were purchased from Seikagaku Kogyo Co. Ltd. (Japan). Keratosulfate was prepared from bovine cornea by the procedure of MEYER et $a l^{9}$. Other reagents used were purchased commercially.

\section{Experimental Methods}

Substrate specificity of hyaluronidase. Corroboration of the degradation of mucopolysaccharides was performed as follows; a test tube containing $1 \mathrm{ml}$ of gastric hyaluronidase solution (1,000 TRU/ml of deionized water) and $1 \mathrm{ml}$ of mucopolysaccharide solution $(2.4 \mathrm{mg} / \mathrm{ml}$ of $0.1 \mathrm{M}$ acetate buffer of $\mathrm{pH} 4.8)$ was kept at $37^{\circ} \mathrm{C}$ for 12 hours. After stopping the reaction by heating the tube in a boiling water bath for 3 minutes,

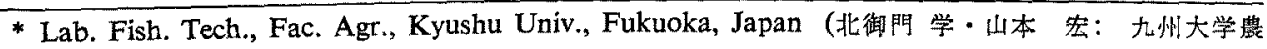
学部水産製造学教室) 
the solution was determined for reducing power by the method of NELSON-SOMOGYI ${ }^{10}$. In control experiment, enzyme and substrate were incubated separately and put together just before the heating.

Determination of hyaluronidase activity. Unless otherwise stated, a mixture of $0.25 \mathrm{ml}$ of gastric hyaluronidase solution suitably diluted with deionized water and $0.25 \mathrm{ml}$ of potassium hyaluronate solution $(2.4 \mathrm{mg} / \mathrm{ml}$ of $0.1 \mathrm{M}$ acetate buffer of $\mathrm{pH} 4.8$ or MCILvaINE buffer of $\mathrm{pH} 2.8$ ) was incubated at $37^{\circ} \mathrm{C}$ for 20 minutes. After the reaction was stopped by heating, $\mathrm{N}$-acetylhexosamine end group released was determined as follows: to the solution was added $0.1 \mathrm{ml}$ of $0.8 \mathrm{M}$ potassium tetraborate solution, and the whole was heated for 3 minutes in a boiling water bath, followed by cooling, mixing with $3 \mathrm{ml}$ of $p$-dimethylaminobenzaldehyde reagent of REISSIG et al. ${ }^{11)}$, and measurement for color development at $544 \mathrm{~m} \mu$. In the case of the reaction carried out in more acidic condition than $\mathrm{pH} 3.0$, a small quantity of $0.5 \mathrm{~N}$ sodium hydroxide solution was added to neutralize the reaction mixture before the determination of $\mathrm{N}$-acetylhexosamine end group. The additive such as salt was added, if necessary, into the buffer solution.

\section{Results and Discussion}

Substrate specificity. Gastric hyaluronidase degraded hyaluronic acid, chondroitin sulfates A, C and D as shown in Table 1. No activity was detected toward heparin, keratosulfate and chitin. It seems that the hyaluronidase exhibites the same substrate specificity as bovine testicular enzyme in consideration of the properties of hyaluronidases obtained from various origins ${ }^{12}$.

Table 1. Substrate specificity of mackerel gastric hyaluronidase.

\begin{tabular}{lc}
\hline \multicolumn{1}{c}{ Mucopolysaccharides } & Degradation \\
\hline Hyaluronic acid & + \\
Chondroitin sulfate A & + \\
Chondroitin sulfate C & + \\
Chondroitin sulfate D & + \\
Heparin & - \\
Keratosulfate & - \\
Chitin & - \\
\hline
\end{tabular}

pH optimum. MCILVAINE buffer indicating various pH was used instead of the buffer described in the experimental methods. The maximum activity of gastric hyaluronidase for hyaluronate occurred at $\mathrm{pH} 4.8$ in the absence of $\mathrm{NaCl}$ as shown in Fig. 1, while at $\mathrm{pH} 2.8$ in the presence of $0.15 \mathrm{M} \mathrm{NaCl}$. The shift of optimum $\mathrm{pH}$ from 4.6 to 3.0 in the absence or presence of $0.15 \mathrm{M} \mathrm{NaCl}$ was observed by using chondroitin sulfate $C$ as a substrate. MAdinaveitia and Quibell ${ }^{13)}$, and Alburn and Whithey ${ }^{14)}$ have reported similar shift of optimum $\mathrm{pH}$ toward bovine testicular hyaluronidase. 


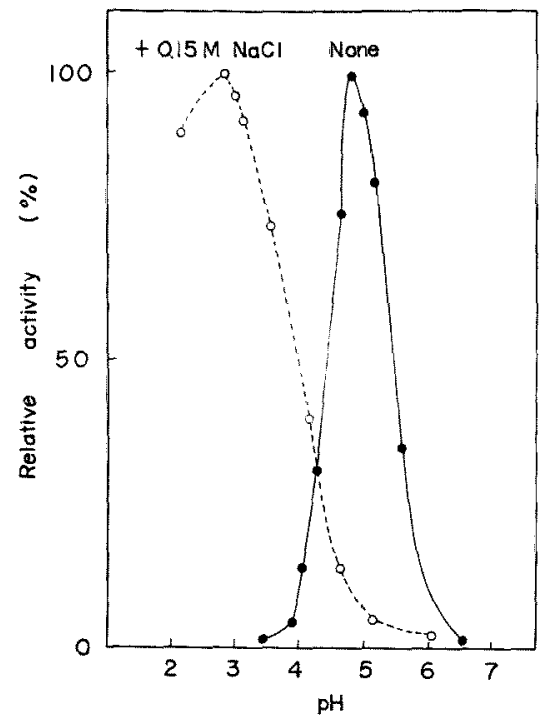

Fig. 1. pH-dependence of the activity of mackerel gastric hyaluronidase at $37^{\circ} \mathrm{C}$.

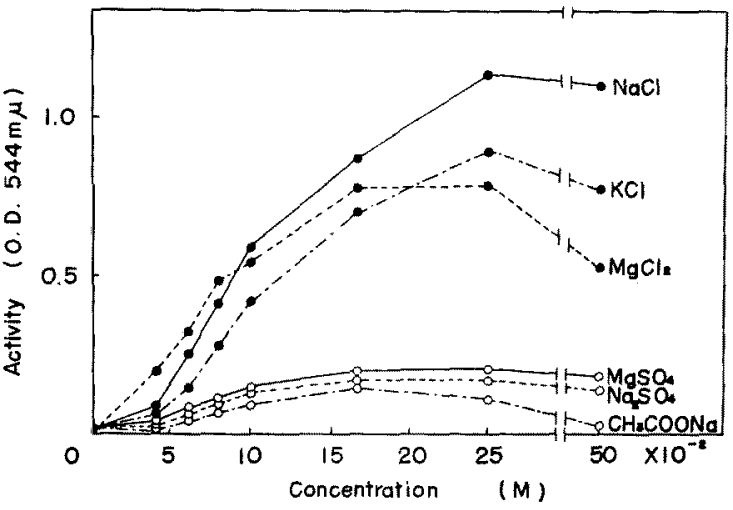

Fig. 2. Effect of salts on the activity of mackerel gastric hyaluronidase at $\mathrm{pH} 2.8$.

Effect of salts. Effect of various salts except those of heavy metals on the activity of gastric hyaluronidase was determined at $\mathrm{pH} 4.8$. As shown in Table 2, various chlo-

Table 2. Effect of salts on the activity of mackerel gastric hyaluronidase at pH 4.8.

\begin{tabular}{lcc}
\hline \multirow{2}{*}{ Salts } & \multicolumn{2}{c}{ Concentration of salts } \\
\cline { 2 - 3 } & $0.01 \mathrm{M}$ & $0.05 \mathrm{M}$ \\
\hline $\mathrm{NaCl}$ & \multicolumn{2}{c}{ Relative activity $(\%)$} \\
$\mathrm{KCl}$ & 238 & 214 \\
$\mathrm{NH}_{4} \mathrm{Cl}$ & 212 & 213 \\
$\mathrm{CH}_{3} \mathrm{COONa}$ & 179 & 159 \\
$\mathrm{NaSO}_{4}$ & 94 & 78 \\
$\mathrm{MgSO}_{4}$ & 113 & 82 \\
$\mathrm{MgCl}_{2}$ & 125 & 97 \\
\hline None & 144 & 116 \\
\hline
\end{tabular}

rides enhanced the activity. The effect of chlorides was conspicuous at $\mathrm{pH} 2.8$ as shown in Fig. 2. It is reasonable to assume that the enhancing effect of chlorides on the activity of gastric hyaluronidase is attributed to $\mathrm{Cl}^{-}$, since the enzyme activity was vigorously inhibited by $5 \times 10^{-3} \mathrm{M} \mathrm{HgCl}_{2}$ as shown in Table 3, but the masking of $\mathrm{Hg}^{++}$with ethylenediaminetetraacetic acid was found to increase the activity. On the one hand, effect of $\mathrm{Ag}^{+}, \mathrm{Zn}^{++}, \mathrm{Cu}^{++}$and $\mathrm{Hg}^{++}$was determined (these heavy metals were tested as acetate). The result in Fig. 3 showed that $\mathrm{Hg}^{++}$at a concentration of $10^{-4} \mathrm{M}$ inhibited the activity 
Table 3. Effect of mercuric chloride and ethylenediaminetetraacetic acid on the activity of mackerel gastric hyaluronidase at $\mathrm{pH} 2.8$.

\begin{tabular}{ccc}
\hline $\begin{array}{c}\mathrm{HgCl}_{2} \\
(\mathrm{M})\end{array}$ & $\begin{array}{c}\text { EDTA } \\
(\mathrm{M})\end{array}$ & $\begin{array}{c}\text { Relative } \\
\text { activity }(\%)\end{array}$ \\
\hline 0 & 0 & 100 \\
$0.5 \times 10^{-3}$ & 0 & 10 \\
0 & $0.5 \times 10^{-2}$ & 122 \\
$0.5 \times 10^{-3}$ & $0.5 \times 10^{-2}$ & 429 \\
\hline
\end{tabular}

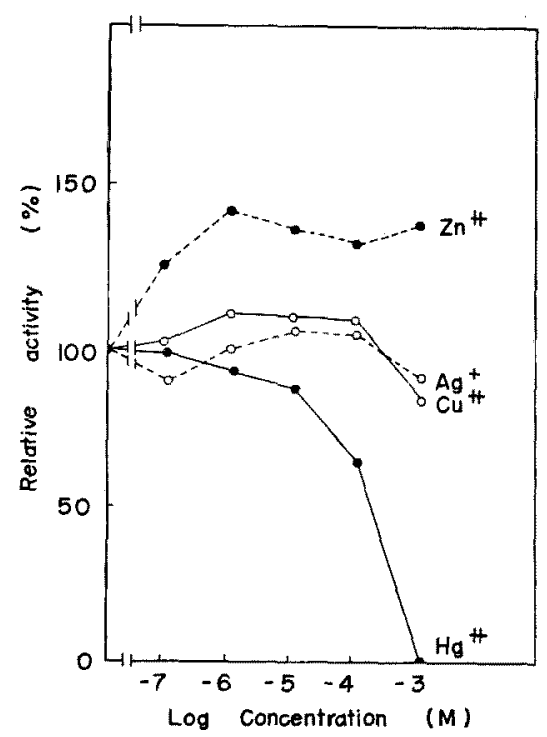

Fig. 3. Effect of heavy metal ions on the activity of mackerel gastirc hyaluronidase at $\mathrm{pH} 4.8$.

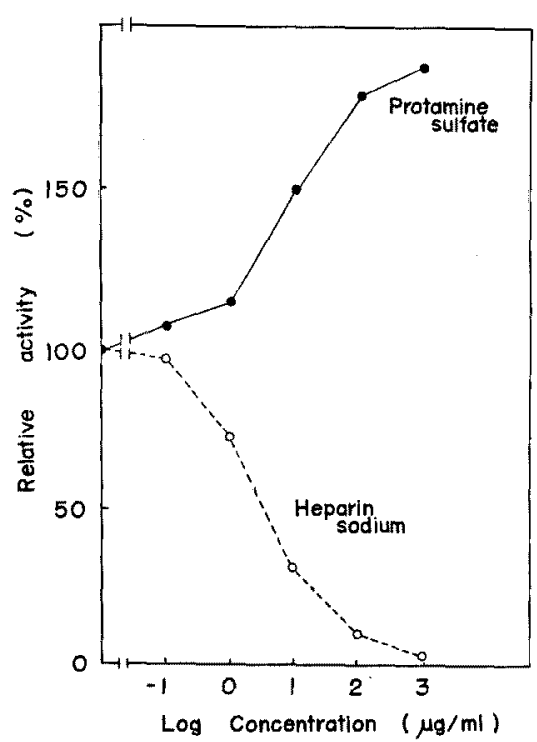

Fig. 4. Effect of macroions on the activity of mackerel gastric hyaluronidase at $\mathrm{pH}$ 4.8 .

of gastric hyaluronidase to approximately $40 \%$ and at $10^{-3} \mathrm{M}$ almost completely, although $\mathrm{Ag}^{+}$and $\mathrm{Cu}^{++}$scarcely affected the activity at $10^{-4} \mathrm{M}$ and $\mathrm{Zn}^{++}$accerated it at the concentrations tested. MEYER and RAPPORT ${ }^{15)}$ have reported that $\mathrm{Ag}^{+}, \mathrm{Zn}^{++}$and $\mathrm{Cu}^{++}$inhibited the activity of bovine testicular hyaluronidase at $10^{-4} \mathrm{M}$ by reversible combination with the enzyme protein. From the above experiments, it is probable to recognize that fish gastric hyaluronidase is more stable than bovine testicular enzyme toward those heavy metal ions.

Effect of macroions. Effect of macroions on the activity of gastric hyaluronidase is shown in Fig. 4. Heparin sodium which acts as a polyanion inhibited the activity, on the contrary protamine sulfate which does as a polycation enhanced it. BERNFEELD et $a{ }^{1{ }^{16)}}$ have reported similar relation between macroions and bovine testicular hyaluronidase.

Temperature-dependence. Activity of gastric hyaluronidase was determined at 
various temperatures, and the result obtained is shown in Fig. 5. The maximum activity is found at approximately $50^{\circ} \mathrm{C}$.

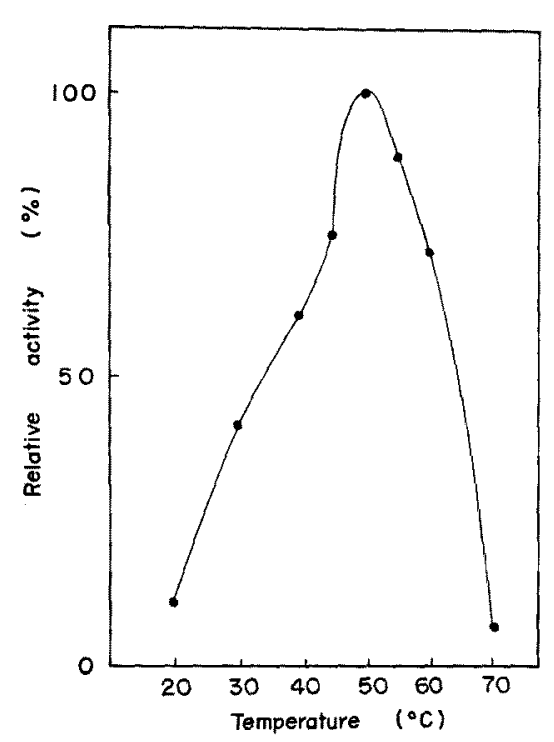

Fig. 5. Temperature-dependence of the activity of mackerel gastric hyaluronidase at pH 4.8.

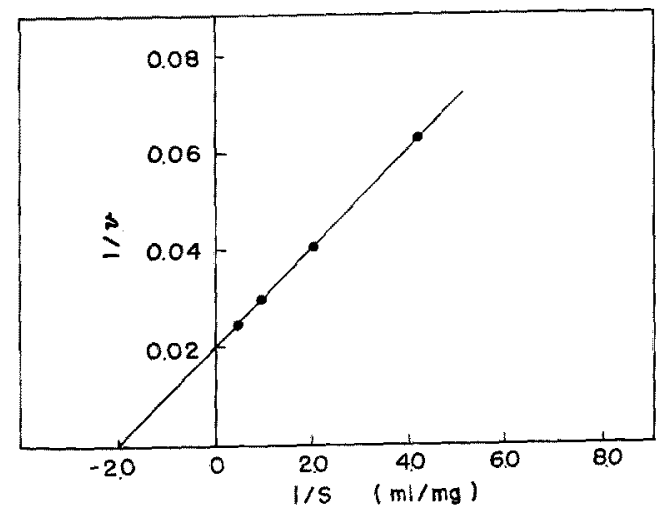

Fig. 7. LINEWEAVER-BURK's prots of mackerel gastric hyaluronidase for potassium hyaluronate at $\mathrm{pH} 4.8$. $v$ : $\mu$ mole of $\mathrm{N}$-acetylglucosamine per $\mathrm{ml}$ of enzyme solution per minute.

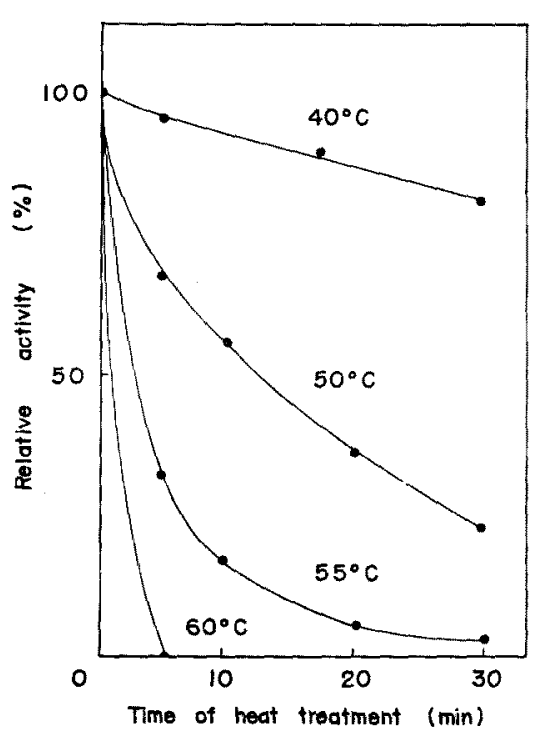

Fig. 6. Stability of mackerel gastric hyaluronidase against heating at $\mathrm{pH} 4.8$.

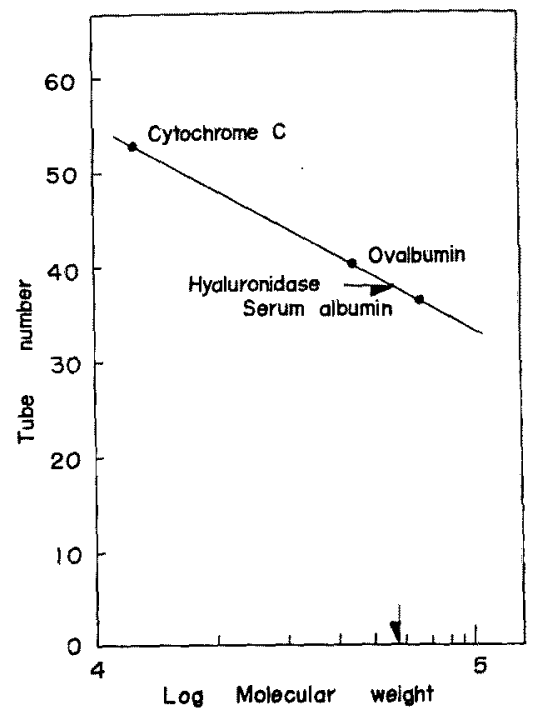

Fig. 8. Molecular weight of mackerel gastric hyaluronidase. 
Stability for heating. Gastric hyaluronidase solution was preincubated with varing temperature and time, and the remaining activity was determined. The result obtainted is shown in Fig. 6. The activity was completely extinguished by the preincubation at $60^{\circ} \mathrm{C}$ for 5 minutes.

MICHAELIS constant. A solution of gastric hyaluronidase (600 TRU/ml) and $0.1 \mathrm{M}$ acetate buffer of $\mathrm{pH} 4.8$ were used. Activity of gastric hyaluronidase was determined with varing the concentration of potassium hyaluronate. The Michaelis constant was $0.50 \mathrm{mg}$ per $\mathrm{ml}$ as shown in Fig. 7.

Molecular weight. The molecular weight of gastric hyaluronidase was estimated by the gel filtration method of ANDrEws. ${ }^{17)}$ From the prot of elution position to the logarithm of molecular weight in Fig. 8, the molecular weight of the hyaluronidase was estimated to be approximately 56,000 .

\section{Acknowledgments}

The authors are very grateful to professor M. Toyomizu for many helpful suggestions and Sansei Seiyaku Co. Ltd. for a gift of potassium hyaluronate. The present study was supported in part by the research fund granted from the Ministry of Education.

\section{References}

1) M. Kitamikado and H. Yamamoto: This Bull., 35, 466-470 (1969).

2) M. KITAMIKADO and H. YAMAMOTO: ibid., 36, 385-390 (1970).

3) H. Yamamoto and M. KitamiKado: ibid., 37, 621-625 (1971).

4) S. Tolksdorf: Method Biochem. Analysis, 1, 429-457 (1954).

5) M. B. Mathews: in "Methods in Enzymology" (E. F. Neufeld and V. Ginsburg ed.), Vol. 8, 657-658, Academic Press, New York and London (1966).

6) S. Gardell: Acta Chem. Scand., 7, 207-215 (1953).

7) T. BITter and H. M. MUTR: Anal. Biochem., 4, 330-334 (1962).

8) C. A. Antonopoulos: Acta Chem, Scand, 16, 1521-1522 (1962).

9) K. Meyer, A. Linker, E. A. Dayidson, and B. Weissmann: J. Biol. Chem., 205, 611-616 (1953).

10) M. Somogyi: ibid, 195, 19-25 (1952).

11) J. L. Reissig, J. L. Strominger, and L. F. Leloir: ibid., 217, 959-966 (1955).

12) K. Meyer, A. Linker, P. Hoffman, and E. D. Korn: Proc. Intern. Symp. Enzyme Chem. Tokyo Kyoto (1957) p. 132, Pergamon Press, England (1959).

13) J. Madinaveitia and T. H. H. Quibell: Biochem. J., 35, 456-460 (1941).

14) H. E. Alburn and R. W. Whitley: J. Biol. Chem., 192, 379-393 (1951).

15) K. Meyer and M. M. RAPPORT: ibid., 188, 485-490 (1951).

16) P. Bernfeld, L. P. Tuttle, and R. W. Hubbard: Arch. Biochem Biophys., 92, $232-239$ (1961).

17) P. ANDREws: Biochem. J., 91, 222-233 (1964). 